\title{
Mid-pliocene Atlantic Meridional Overturning Circulation not unlike modern
}

\author{
Z.-S. Zhang ${ }^{1,2,3}$, K. H. Nisancioglu ${ }^{1,2,4}$, M. A. Chandler ${ }^{5}$, A. M. Haywood ${ }^{6}$, B. L. Otto-Bliesner ${ }^{7}$, G. Ramstein ${ }^{8}$, \\ C. Stepanek ${ }^{9}$, A. Abe-Ouchi ${ }^{10,11}$, W.-L. Chan ${ }^{10}$, F. J. Bragg ${ }^{12}$, C. Contoux ${ }^{9,13}$, A. M. Dolan ${ }^{6}$, D. J. Hill ${ }^{6,14}$, A. Jost ${ }^{13}$, \\ Y. Kamae ${ }^{15}$, G. Lohmann ${ }^{9,16}$, D. J. Lunt ${ }^{11}$, N. A. Rosenbloom ${ }^{7}$, L. E. Sohl ${ }^{5}$, and H. Ueda ${ }^{15}$ \\ ${ }^{1}$ UNI Research, Allegaten 55, 5007 Bergen, Norway \\ ${ }^{2}$ Bjerknes Centre for Climate Research, Allegaten 55, 5007 Bergen, Norway \\ ${ }^{3}$ Nansen-Zhu International Research Center, Institute of Atmospheric Physics, Chinese Academy of Sciences, \\ 100029, Beijing, China \\ ${ }^{4}$ Department of Earth Science, University of Bergen, Allegaten 41, 5007 Bergen, Norway \\ ${ }^{5}$ CCSR/GISS, Columbia University, Columbia, New York, USA \\ ${ }^{6}$ School of Earth and Environment, University of Leeds, Woodhouse Lane, Leeds, S29JT, UK \\ ${ }^{7}$ National Center for Atmospheric Research, Boulder, Colorado, USA \\ ${ }^{8}$ LSCE/IPSL, CNRS-CEA-UVSQ, Saclay, France \\ ${ }^{9}$ Alfred Wegener Institute, Helmholtz Centre for Polar and Marine Research, Bremerhaven, Germany \\ ${ }^{10}$ Atmosphere and Ocean Research Institute, University of Tokyo, Kashiwa, Japan \\ ${ }^{11}$ Research Institute for Global Change, Japan Agency for Marine-Earth Science and Technology, Yokohama, Japan \\ ${ }^{12}$ BRIDGE, School of Geographical Sciences, University of Bristol, University Road, Bristol, BS8 1SS, UK \\ ${ }^{13}$ Sisyphe, CNRS/UPMC Univ Paris 06, Paris, France \\ ${ }^{14}$ British Geological Survey, Keyworth, Nottingham, NG12 5GG, UK \\ ${ }^{15}$ Graduate School of Life and Environmental Sciences, University of Tsukuba, Tsukuba, Japan \\ ${ }^{16}$ Institute for Environmental Physics, University of Bremen, Bremen, Germany
}

Correspondence to: Z.-S. Zhang (zhongshi.zhang@bjerknes.uib.no)

Received: 25 February 2013 - Published in Clim. Past Discuss.: 7 March 2013

Revised: 5 June 2013 - Accepted: 6 June 2013 - Published: 15 July 2013

\begin{abstract}
In the Pliocene Model Intercomparison Project (PlioMIP), eight state-of-the-art coupled climate models have simulated the mid-Pliocene warm period (mPWP, 3.264 to $3.025 \mathrm{Ma}$ ). Here, we compare the Atlantic Meridional Overturning Circulation (AMOC), northward ocean heat transport and ocean stratification simulated with these models. None of the models participating in PlioMIP simulates a strong mid-Pliocene AMOC as suggested by earlier proxy studies. Rather, there is no consistent increase in AMOC maximum among the PlioMIP models. The only consistent change in AMOC is a shoaling of the overturning cell in the Atlantic, and a reduced influence of North Atlantic Deep Water (NADW) at depth in the basin. Furthermore, the simulated mid-Pliocene Atlantic northward heat transport is similar to the pre-industrial. These simulations demonstrate that the
\end{abstract}

reconstructed high-latitude mid-Pliocene warming can not be explained as a direct response to an intensification of AMOC and concomitant increase in northward ocean heat transport by the Atlantic.

\section{Introduction}

The mid-Pliocene warm period (mPWP; 3.264 to $3.025 \mathrm{Ma}$, Dowsett et al., 2012) is the most recent geological period in the past with global temperatures $\sim 2-3^{\circ} \mathrm{C}$ warmer than present (Haywood and Valdes, 2004), corresponding to atmospheric greenhouse gas levels significantly above preindustrial levels (Seki et al., 2010). This period is thought to be an analogue for a future greenhouse climate and shares 
Table 1. Comparison of the eight models that have performed coupled simulations in the PlioMIP.

\begin{tabular}{|c|c|c|c|c|c|c|c|c|c|}
\hline \multirow[t]{2}{*}{ Model } & \multirow{2}{*}{$\begin{array}{l}\text { Ocean } \\
\text { resolution }\end{array}$} & \multirow{2}{*}{$\begin{array}{l}\text { Vertical/diapycnal } \\
\text { mixing }\end{array}$} & \multicolumn{2}{|c|}{ I. length/mean (years) ${ }^{1}$} & \multicolumn{3}{|c|}{ Max AMOC } & \multirow{2}{*}{$\begin{array}{r}\mathrm{OHT}^{4} \\
(\%)\end{array}$} & \multirow[t]{2}{*}{ Reference } \\
\hline & & & $\mathrm{PI}^{2}$ & $\mathrm{MP}^{3}$ & PI & MP & $(\%)$ & & \\
\hline CCSM4 & $\begin{array}{l}\sim 1^{\circ} \times 1^{\circ} \\
\text { L60 depth }\end{array}$ & $\begin{array}{l}k \text { from } 0.01 \times 10^{-4} \text { to } \\
0.30 \times 10^{-4} \mathrm{~m}^{2} \mathrm{~s}^{-1} \\
\text { latitudinally varying }\end{array}$ & $1300 / 100$ & $550 / 100$ & 25.7 & 24.6 & $-4 \%$ & $-4 \%$ & $\begin{array}{l}\text { Rosenbloom et al. } \\
\text { (2013) }\end{array}$ \\
\hline COSMOS & $\begin{array}{l}\sim 3.0^{\circ} \times 1.8^{\circ} \\
\text { L40 depth }\end{array}$ & $k=0.105 \times 10^{-4} \mathrm{~m}^{2} \mathrm{~s}^{-1}$ & $3000 / 30$ & $1000 / 30$ & 16.8 & 17.4 & $4 \%$ & $6 \%$ & $\begin{array}{l}\text { Stepanek } \\
\text { and Lohmann (2012) }\end{array}$ \\
\hline GISS-ModelE2-R & $\begin{array}{l}1^{\circ} \times 1.25^{\circ} \\
\text { L32 depth }\end{array}$ & $\begin{array}{l}\mathrm{KPP}^{5} \text { with non-local fluxes, } \\
k=0.1 \times 10^{-4} \mathrm{~m}^{2} \mathrm{~s}^{-1}\end{array}$ & $950 / 30$ & $950 / 30$ & 14.3 & 17.9 & $25 \%$ & $4 \%$ & $\begin{array}{l}\text { Chandler et al. } \\
\text { (2013) }\end{array}$ \\
\hline HadCM3 & $\begin{array}{l}1.25^{\circ} \times 1.25^{\circ} \\
\mathrm{L} 20 \text { depth }\end{array}$ & $k=0.1 \times 10^{-4} \mathrm{~m}^{2} \mathrm{~s}^{-1}$ & $200 / 50$ & $500 / 50$ & 17.6 & 18.5 & $5 \%$ & $-7 \%$ & $\begin{array}{l}\text { Bragg et al. } \\
(2012)\end{array}$ \\
\hline IPSLCM5A & $\begin{array}{l}0.5-2^{\circ} \times 2^{\circ} \\
\text { L31 depth }\end{array}$ & function of $\mathrm{TKE}^{6}$ & $2800 / 100$ & $730 / 30$ & 10.2 & 10.0 & $-2 \%$ & $2 \%$ & $\begin{array}{l}\text { Contoux et al. } \\
\text { (2012) }\end{array}$ \\
\hline MIROC4m & $\begin{array}{l}0.56-1.4^{\circ} \times 1.4^{\circ}, \\
\text { L43 sigma/depth }\end{array}$ & $\begin{array}{l}k \text { from } 0.1 \times 10^{-4} \mathrm{~m}^{2} \mathrm{~s}^{-1} \text { to } \\
3.0 \times 10^{-4} \mathrm{~m}^{2} \mathrm{~s}^{-1}, \\
\text { latitudinally varying }\end{array}$ & $3800 / 100$ & $1400 / 100$ & 19.7 & 19.5 & $-1 \%$ & $-11 \%$ & Chan et al. (2011) \\
\hline MRI-CGCM2.3 & $\begin{array}{l}0.5-2.0^{\circ} \times 2.5^{\circ} \\
\text { L23 depth }\end{array}$ & $\begin{array}{l}k=0.1 \times 10^{-4} \mathrm{~m}^{2} \mathrm{~s}^{-1} \\
\text { varying in depth }\end{array}$ & $1000 / 50$ & $500 / 50$ & 16.6 & 20.5 & $23 \%$ & $3 \%$ & $\begin{array}{l}\text { Kamae and Ueda } \\
\text { (2012) }\end{array}$ \\
\hline NorESM-L & $\begin{array}{l}\sim 3^{\circ} \times 3^{\circ}, \\
\text { L32 sigma }\end{array}$ & $\begin{array}{l}k=0.1 \times 10^{-4} \mathrm{~m}^{2} \mathrm{~s}^{-1} \\
\text { latitudinally varying }\end{array}$ & $1500 / 200$ & $1500 / 200$ & 21.8 & 23.4 & $7 \%$ & $-14 \%$ & $\begin{array}{l}\text { Zhang et al. } \\
\text { (2012) }\end{array}$ \\
\hline
\end{tabular}

${ }^{1}$ The column shows the length of integration/climatological means for each experiment. ${ }^{2}$ PI means pre-industrial. ${ }^{3}$ MP means mid-Pliocene. ${ }^{4}$ OHT shows changes in the northward ocean heat transport by the Atlantic. ${ }^{5}$ KPP means K-Profile parameterization. ${ }^{6}$ TKE means turbulent kinetic energy.

similarities with climate projections of the Intergovernmental Panel on Climate Change (IPCC; Jansen et al., 2007; Meehl et al., 2007). However, unlike the projections for the end of this century, the MPWP is thought to have been in equilibrium with the radiative forcing at the time, allowing for an adjustment of the slow components of the climate system such as the deep ocean and land-based ice sheets. This could explain the estimates of high global sea level for the period, with a range of 10-40 $\mathrm{m}$ above present (Raymo et al., 2011; Miller et al., 2012), implying that the Antarctic and Greenland ice sheets were smaller than at present.

Based on marine proxy data, it has been inferred that the Atlantic Meridional Overturning Circulation (AMOC) was significantly stronger in the mPWP compared to today (Raymo et al., 1996; Ravelo and Andreasen, 2000; Frank et al., 2002; Frenz et al., 2006; Dowsett et al., 2009; McKay et al., 2012). A stronger AMOC could have contributed to enhanced northward heat transport, thus explaining the remarkable warming in the North Atlantic at the time (Dowsett et al., 1992, 2009; Lawrence et al., 2010; Naafs et al., 2012). However, the control of the AMOC on transport of heat to high latitudes, and thereby high-latitude ocean surface temperature, is questionable (e.g. Wunsch, 2005). A strong AMOC has also been used to explain a weak Atlantic meridional ${ }^{13} \mathrm{C}$ gradient during the mid-Pliocene (Raymo et al., 1996; Ravelo and Andreasen, 2000). However, the observed weak Atlantic $\delta^{13} \mathrm{C}$ gradient in the mPWP and its relationship to AMOC strength is unclear (Hodell and Venz-Curtis, 2006).
Since the mid-Pliocene palaeoenvironmental reconstructions were released (Dowsett et al., 1992, 1994, 1996, 1999), an increasing number of modelling studies have focused on understanding the mPWP climate (Chandler et al., 1994; Sloan et al., 1996; Haywood et al., 2000; Haywood and Valdes, 2004; Jiang et al., 2005; Yan et al., 2011). Although these models can account for the general pattern of warming in the reconstructed mPWP sea surface temperature (SST), there is no consistent pattern of a strong AMOC in the experiments (Haywood and Valdes, 2004; Yan et al., 2011).

In order to increase our understanding of mPWP climate, and better integrate proxy-based studies with dynamical modelling, the Pliocene Model Intercomparison Project (PlioMIP) was initiated (Haywood et al., 2010, 2011). The aim of PlioMIP is to simulate the MPWP in a suite of atmosphere general circulation models and coupled atmosphereocean general circulation models, with the same boundary conditions (Haywood et al., 2010, 2011) applied. Currently fourteen modelling groups participate in the PlioMIP (Haywood et al., 2013a), of which eight (Chan et al., 2011; Bragg et al., 2012; Chandler et al., 2013; Contoux et al., 2012; Kamae and Ueda, 2012; Rosenbloom et al., 2013; Stepanek and Lohmann, 2012; Zhang et al., 2012) have completed coupled simulations and submitted data to the PlioMIP database (Table 1).

In this study, we analyse these eight mid-Pliocene simulations, with a focus on the Atlantic Meridional Overturning Circulation. We seek through this model intercomparison to 
better understand the possible changes in Atlantic Ocean circulation and climate during the mPWP.

The paper is structured as follows: Sect. 2 reviews geological reconstructions of ocean circulation and climate during the mid-Pliocene; Sect. 3 compares the simulated climatological means of AMOC, northward ocean heat transport, and ocean stratification in the Atlantic; Sect. 4 discusses the model results in relation to the proxy data, and also contains a summary.

\section{Geological evidence for changes in mPWP ocean circulation and climate}

Most geological data available for the mid-Pliocene ocean are reconstructions of ocean temperature. The Pliocene Research, Interpretation and Synoptic Mapping version 3 (PRISM3, Dowsett et al., 2009) provides a dataset of SST and deep ocean temperature for the peak warm period in the mid-Pliocene (3.264 to $3.025 \mathrm{Ma}$ ). Reconstructed midPliocene SSTs from Atlantic drill sites show a strong warming at high latitudes, in particular in the Northern Hemisphere. In the North Atlantic, the largest warming appears at Deep Sea Drilling Project (DSDP) Site 548, with reconstructed SSTs $\sim 10^{\circ} \mathrm{C}$ warmer in August and $\sim 7^{\circ} \mathrm{C}$ warmer in February, compared to present (Table 1 in Dowsett et al., 2009). In the Southern Ocean/South Atlantic, the largest warming occurs at Ocean Drilling Program (ODP) Site 704 (Table 1 in Dowsett et al., 2009), with reconstructed midPliocene SSTs $\sim 2{ }^{\circ} \mathrm{C}$ warmer in both February and August, compared to today. Furthermore, PRISM3 provides reconstructed global monthly SST maps for the mPWP (Dowsett et al., 2009). These maps illustrate an extreme warming in the Norwegian and Greenland seas, with August SSTs increased by $20^{\circ} \mathrm{C}$, and February SSTs increased by $11^{\circ} \mathrm{C}$, compared to today. In addition to the SST reconstructions, PRISM3 provides a reconstruction of deep ocean temperatures at 27 drill sites. 20 of these indicate that mid-Pliocene ocean temperatures were warmer than modern. The largest increase in temperature $\left(4.2^{\circ} \mathrm{C}\right)$ appears at ODP Site 704 in the Southern Ocean/South Atlantic (Dowsett et al., 2009).

The extremely warm SSTs in the North Atlantic were firstly suggested to be caused by an increased ocean heat transport during the mPWP (Dowsett et al., 1992). Then, a low meridional $\delta^{13} \mathrm{C}$ gradient was found in the warm midPliocene Atlantic, which could indicate a much stronger mid-Pliocene AMOC that increased the ocean transport. Raymo et al. (1996) found the low $\delta^{13} \mathrm{C}$ gradient between DSDP Sites 552 and 607 in the North Atlantic and ODP Site 704 in the Southern Ocean/South Atlantic, and thus concluded that North Atlantic Deep Water (NADW) production was significantly stronger in the warm Pliocene relative to the cold late Quaternary. This idea was later supported by a synthesis of benthic foraminiferal $\delta^{13} \mathrm{C}$ by Ravelo and Andreasen (2000). Further, Hodell and
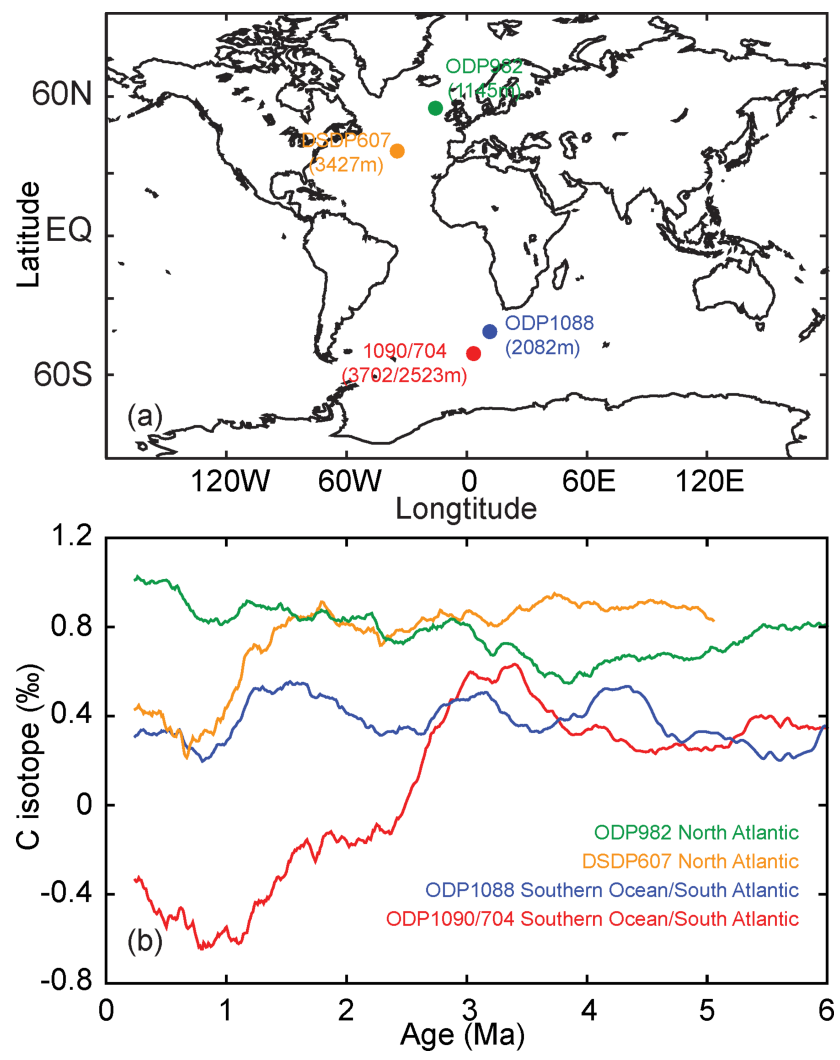

Fig. 1. $\delta^{13} \mathrm{C}$ data in the Atlantic. (a) Site position and depth plotted in a global map. (b) $\delta^{13} \mathrm{C}$ records from Site 982, 607, 1088 and $1090 / 704$. The ${ }^{13} \mathrm{C}$ data are taken from Hodell and Venz-Curtis (2006), the interpolated and 50-point smoothed ${ }^{13} \mathrm{C}$.

Venz-Curtis (2006) compared the benthic foraminiferal $\delta^{13} \mathrm{C}$ from DSDP Site 607 and ODP Sites 982, 1088, 704/1090, and 849. This later study illustrated that the meridional $\delta^{13} \mathrm{C}$ gradient was low during the mPWP compared to the late Quaternary. However, the low $\delta^{13} \mathrm{C}$ gradient was mainly caused by the reconstructed high $\delta^{13} \mathrm{C}$ levels from Sites 1090/704 in the deep Southern Ocean/South Atlantic (Fig. 1).

Other geological evidence includes productivity and nutrient reconstructions. Productivity indicators reveal that biogenic opal accumulation was higher in the mid-Pliocene in the Southern Ocean (Hillenbrand et al., 2001; Sigman et al., 2004, McKay et al., 2012). Opal data, together with ${ }^{15} \mathrm{~N} /{ }^{14} \mathrm{~N}$, indicate that nutrient supply from the depth to the surface was greater in the mid-Pliocene than the late Quaternary, suggesting a weakly stratified Southern Ocean/South Atlantic during the mid-Pliocene (Sigman et al., 2004). Following the midPliocene, ocean stratification increased in the polar oceans (Sigman et al., 2004), and inorganic dust proxies demonstrate that iron input was enhanced in the Southern Ocean (Martines-Garcia et al., 2011). 

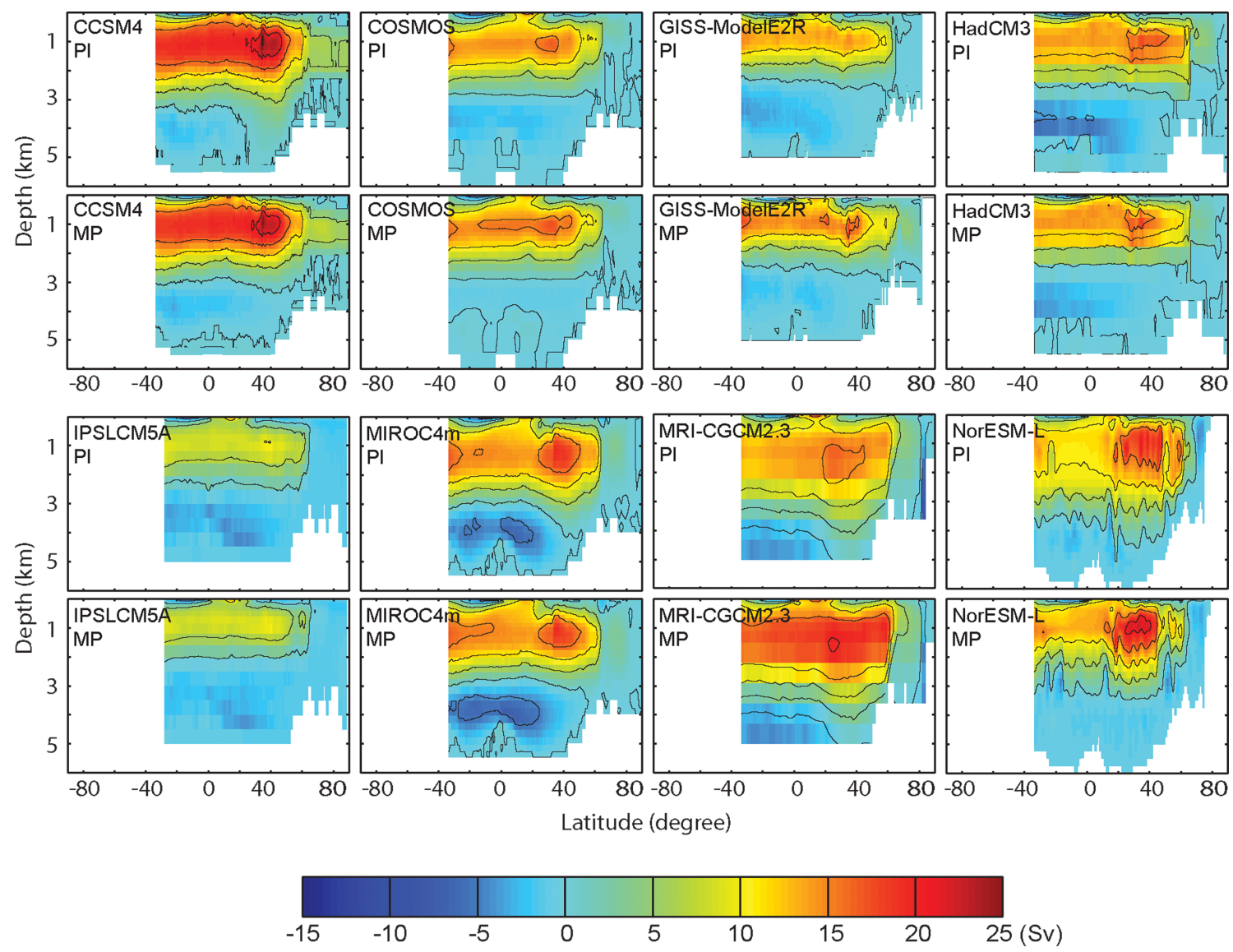

Fig. 2. Comparison of pre-industrial (PI) and mid-Pliocene (MP) Atlantic overturning streamfunctions (Sv) simulated in the PlioMIP. The interval of black contours is $5 \mathrm{~Sv}$.

\section{Simulated mid-Pliocene ocean circulation}

\subsection{Atlantic Meridional Overturning Circulation}

The PlioMIP models simulate a reasonable pre-industrial AMOC with maximum values of the meridional overturning streamfunction in the range from 10 to $26 \mathrm{~Sv}$ (Fig. 2, Table 1). The depth of the AMOC cell is highly modeldependent, ranging from 2000 to $4000 \mathrm{~m}$.

Compared to the pre-industrial control runs, three models simulate slightly weaker mid-Pliocene AMOC maximum values (CCSM4, IPSLCM5A and MIROC4m, with 4, 2 and $1 \%$ reduction, respectively). The remaining models simulate stronger mid-Pliocene AMOC maximum values (COSMOS, HadCM3, NorESM-L, MRI_CGCM2.3, and GISS-ModelE2-R, with 4, 5, 7, 23, and $25 \%$ increase, respectively).

However, perhaps more significant is the observed change in the depth of the AMOC cell in the simulations of the two time periods. The AMOC cell is shifted to shallower depths in the mid-Pliocene experiments in all the models except for COSMOS and GISS-ModelE2-R (Fig. 3a). Although the AMOC maximum increases in the mid-Pliocene experiments

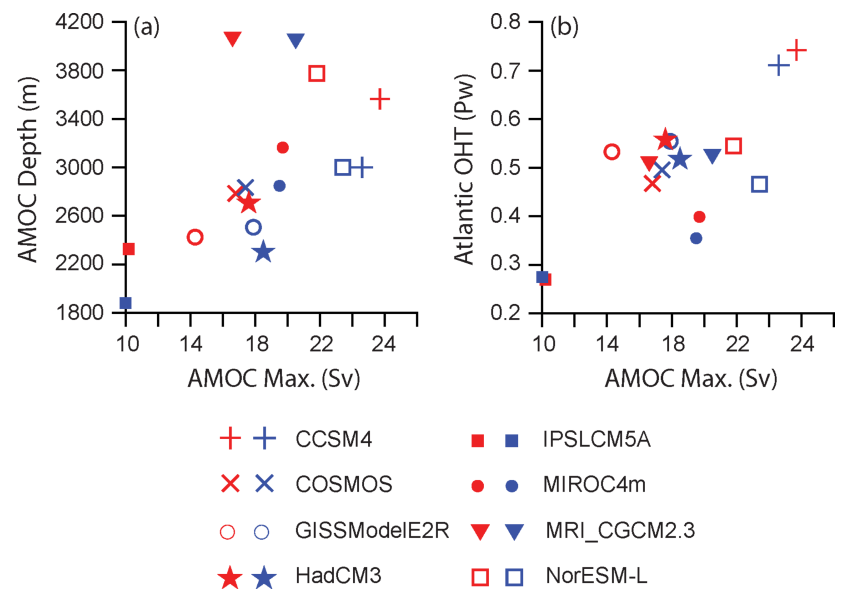

Fig. 3. (a) Maximun AMOC values vs. mean depths of AMOC cells. (b) Maximun AMOC values vs. mean values of ocean heat transport in Atlantic between $30^{\circ} \mathrm{S}$ and $80^{\circ} \mathrm{N}$. Pre-industrial experiments are marked in red, and mid-Pliocene experiments are in blue. 


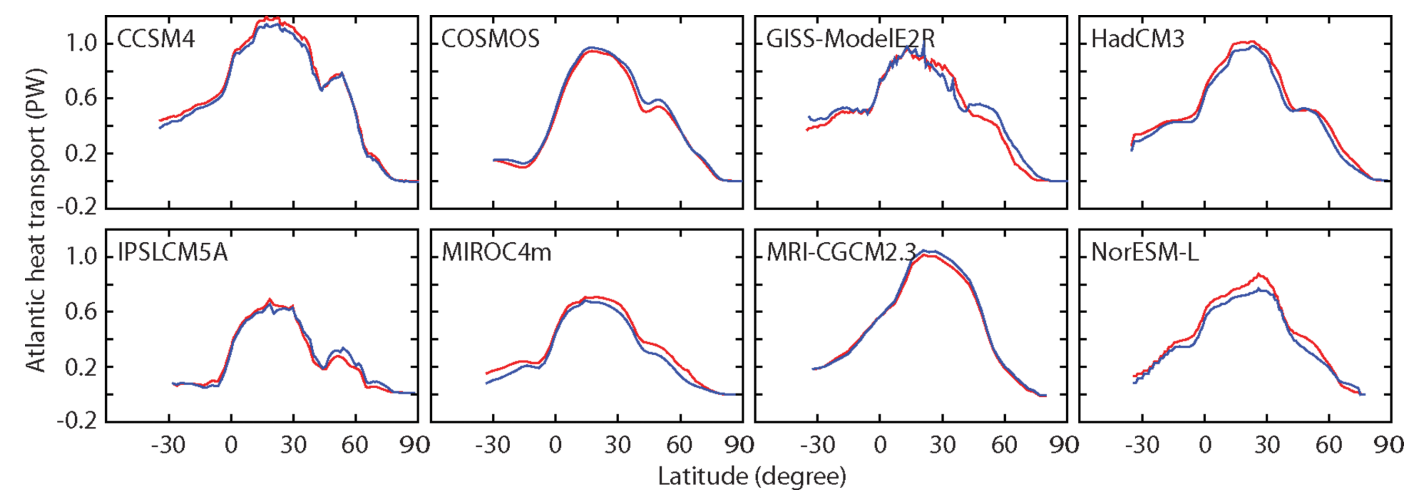

Fig. 4. Comparison of pre-industrial (red) and mid-Pliocene (blue) Atlantic northward ocean heat transport (PW) simulated in the PlioMIP.

simulated with HadCM3, NorESM-L, and MRI_CGCM2.3, no increases in AMOC depth are observed in these simulations. This implies that for each model there is no consistent increase in the depth of AMOC cell with an increase in its maximum. On the other hand, if all eight models are considered together, there is a positive relationship between AMOC maximums and depths.

\subsection{Northward Atlantic Ocean heat transport}

The PlioMIP models simulate reasonable northward ocean heat transport by the Atlantic in all pre-industrial control experiments. The simulated Atlantic heat transport agrees with the observational-based estimates (Trenberth and Caron, 2001), though the IPSLCM5A and MIROC4m simulate a slightly weaker Atlantic heat transport.

Compared to the pre-industrial control runs, four models (CCSM4, HadCM3, MIROC4m, NorESM-L) simulate weaker Atlantic northward ocean heat transport (with 4, 7, 11 and $14 \%$ reduction in mean Atlantic heat transport between $30^{\circ} \mathrm{S}$ and $80^{\circ} \mathrm{N}$, respectively) in the mid-Pliocene experiments (Fig. 4). Although less heat is transported by the ocean to the high-latitude North Atlantic, a warming is nevertheless simulated in the high-latitude North Atlantic surface ocean in these mid-Pliocene experiments (see the model intercomparison by Haywood et al., 2013a). In particular, although northward ocean heat transport in the Atlantic is weaker in the mid-Pliocene experiment with NorESM-L, the simulated scale of SST increase is in good agreement with the reconstructed North Atlantic SST in PRISM3 (Zhang et al., 2013).

Four models (IPSLCM5A, MRI_CGCM2.3, GISSModelE2-R, and COSMOS) simulate a slightly stronger mid-Pliocene northward ocean heat transport in the Atlantic (with 2, 3, 4 and 6\% increases in mean Atlantic heat transport between $30^{\circ} \mathrm{S}$ and $80^{\circ} \mathrm{N}$, respectively), compared to the pre-industrial control runs. In the experiments with MRI_CGCM2.3, GISS-ModelE2-R and COSMOS, the stronger northward ocean heat transport is concomitant with an increased AMOC maximum (Fig. 3b). In these three models, the simulated depth of the mid-Pliocene AMOC cell remains nearly the same as in the pre-industrial experiment. In contrast, the IPSLCM5A model shows an enhanced mid-Pliocene Atlantic heat transport, despite a weaker AMOC. The reason for this is that the northward ocean heat transport by the horizontal gyre circulation is increased.

\section{Ocean stratification in the Atlantic section}

All pre-industrial experiments simulate similar Atlantic salinity structures (Fig. 5) characterized by salty NADW water produced between $20^{\circ} \mathrm{N}$ and $60^{\circ} \mathrm{N}$ in the North Atlantic; relatively fresh Antarctic Intermediate Water extending from the Southern Ocean northward into the South Atlantic at a depth of about 1000m; and Antarctic Bottom Water is produced in the Southern Ocean and fills the abyssal Atlantic Ocean. The simulated salinity structures indicate that the simulated ocean stratification agrees with observations in the Atlantic (Koltermann et al., 2011; http://www-pord.ucsd.edu/whp_atlas/atlantic/a16/ sections/printatlas/A16CTDSAL.jpg).

Compared to the pre-industrial control runs, the models show small changes in simulated North Atlantic salinity structure for the mid-Pliocene. There is a slight increase in salinity of NADW; however, the changes are small and not consistent among all models. In the Southern Ocean/South Atlantic, all models except for NorESM-L simulate similar salinity structures in the pre-industrial and mid-Pliocene experiments, indicating that the simulated mid-Pliocene ocean stratification is similar to the pre-industrial in the Southern Ocean/South Atlantic. In contrast, the simulated weak vertical salinity gradient in the upper $\sim 4 \mathrm{~km}$ of the isopycnal ocean of NorESM-L indicates a weakly stratified Southern Ocean/South Atlantic in the mid-Pliocene experiment. An indepth discussion of this can be found in Zhang et al. (2013). 

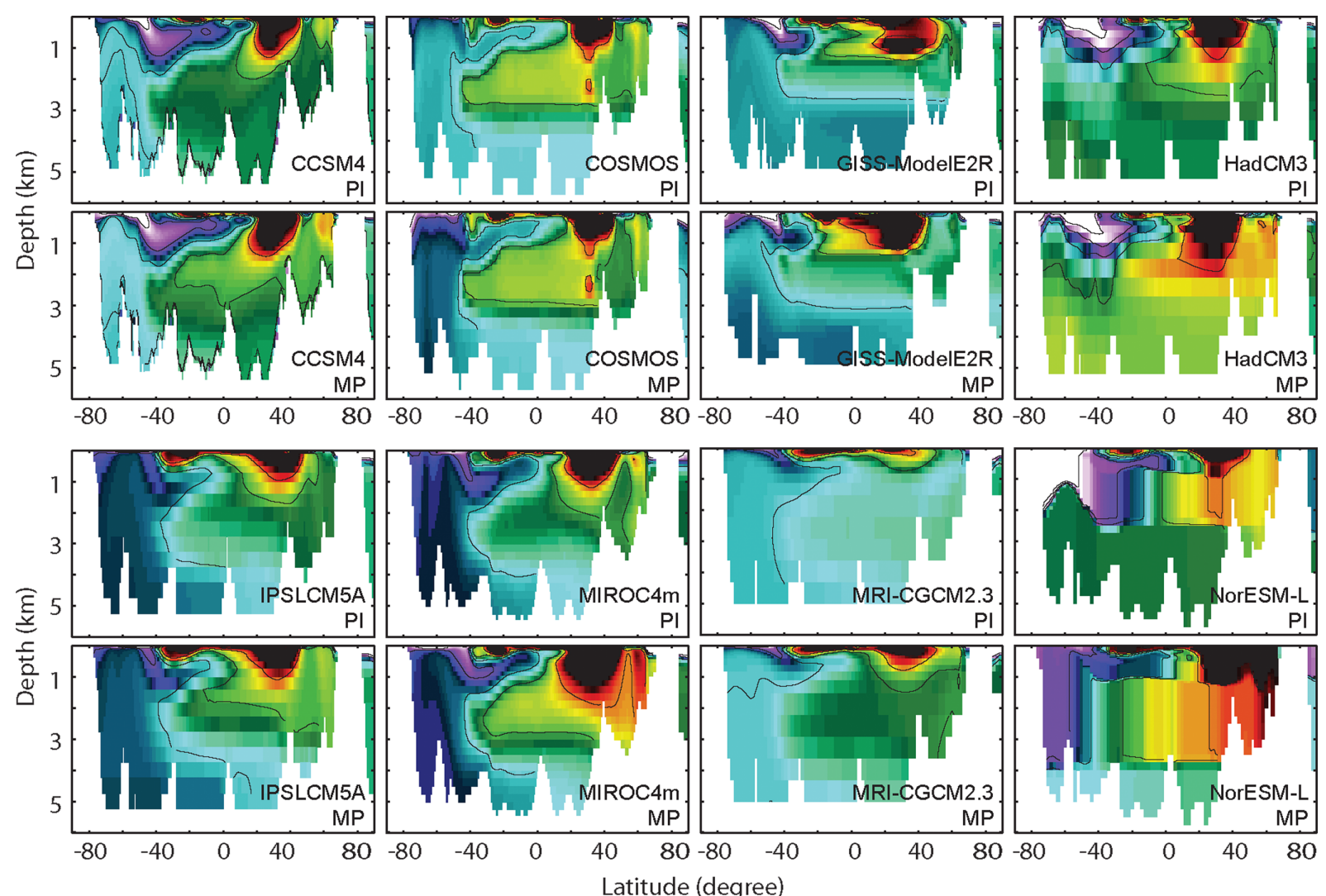

Latitude (degree)

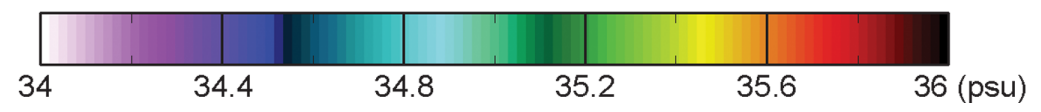

Fig. 5. Comparsion of pre-industrial (PI) and mid-Pliocene (MP) salinity (psu) profiles at $30^{\circ} \mathrm{W}$ simulated in the PlioMIP. The interval of the black contour is 0.4 psu.

\section{Discussion and summary}

The above comparison of coupled atmosphere-ocean simulations of mPWP climate in the PlioMIP shows small changes in the maximum of the Atlantic Meridional Overturning Circulation. There is no consistent increase in AMOC maximums among the models (Fig. 3a). However, most models simulate a shoaling of the AMOC cell in the mid-Pliocene experiments.

Although there is a significant model spread, none of models simulates a significant increase in northward ocean heat transport (Fig. 3b). Earlier studies suggest that a significant increase in northward ocean heat transport, caused by a strengthening of the AMOC, is required in order to explain the surface warming of the high-latitude North Atlantic in the mid-Pliocene. However, the PlioMIP simulations presented here do not support this theory. Even in the models (MRI_CGCM2.3 and GISS-ModelE2-R) which show a large increase in AMOC maximum, the heat transport does not increase significantly ( 3 and $4 \%$ ). Therefore, based on the PlioMIP model results, changes in the AMOC or Atlantic
Ocean heat transport do not play a dominant role in setting the pattern of North Atlantic SST during the mPWP.

However, it should be stressed that these findings do not imply that the structure of mid-Pliocene Atlantic Ocean circulation is equivalent to the pre-industrial/late Quaternary. The mid-Pliocene Atlantic Ocean circulation is clearly different from pre-industrial/late Quaternary; for example, the mid-Pliocene North Atlantic surface is much warmer than pre-industrial/late Quaternary (Dowsett et al., 2009). However, these changes should not be simply attributed to a stronger AMOC. A more likely candidate for the reconstructed North Atlantic surface warming is increased radiative surface forcing, which is dominated by increased atmospheric $\mathrm{CO}_{2}$ levels, solar insolation (Haywood et al., 2013b), and the reduced size of the Greenland ice sheet (Lunt et al., 2012).

The similarity between mid-Pliocene and modern AMOC is, to first order, consistent with marine $\delta^{13} \mathrm{C}$ records (Fig. 1). At Site 982 (Venz et al., 1999; Venz and Hodell, 2002; Hodell and Venz-Curtis, 2006), which is located at the latitude where modern NADW originates, relatively small changes in $\delta^{13} \mathrm{C}$ 
are recorded since the $\mathrm{mPWP}$, indicating that the formation of NADW is similar between the MPWP and late Quaternary. In other words, simulations of weak, or nearly absent AMOC in the mPWP (with modern tropical seaway conditions) is not supported by proxy data. This could also have implications for our understanding of the future long-term response of the AMOC to elevated levels of greenhouse gases, as the simulated weak AMOC found in the IPCC experiments could be a transient feature of the model response (Meehl et al., 2007).

Although the local changes in the North Atlantic are small, the meridional $\delta^{13} \mathrm{C}$ gradient in the Atlantic is known to have changed significantly when comparing the mid-Pliocene and late Quaternary (Fig. 1). The weak $\delta^{13} \mathrm{C}$ gradient during the mPWP has often served as evidence for a stronger midPliocene AMOC, as intensified production of NADW (dominated by high $\delta^{13} \mathrm{C}$ ) could bring water with higher levels of preformed $\delta^{13} \mathrm{C}$ water to the Southern Ocean, thus reducing the Atlantic meridional $\delta^{13} \mathrm{C}$ gradient (Oppo and Fairbanks, 1987; Wright and Miller, 1996; Dowsett et al., 2009).

However, the recent compilation of $\delta^{13} \mathrm{C}$ by Hodell and Venz-Curtis (2006) suggests an alternative explanation that the observed weak mPWP meridional $\delta^{13} \mathrm{C}$ gradient is caused by the introduction of water with high $\delta^{13} \mathrm{C}$ in the Southern Ocean (Site 1090/704, Venz and Hodell, 2002; Hodell and Venz-Curtis, 2006) during the mPWP. In contrast, changes of $\delta^{13} \mathrm{C}$ in mid-depth of the Southern Ocean/South Atlantic (Site 1088, Hodell and Venz-Curtis, 2006) and in the North Atlantic (Sites 607 and 982, Raymo et al., 1992; Venz et al., 1999; Venz and Hodell, 2002; Hodell and Venz-Curtis, 2006) are relatively small. Even when considering changes in $\delta^{13} \mathrm{C}$ from others sites in the North Atlantic (Sites 999, 925, and 981/982, Bickert et al., 1997; Billups et al., 1997; Haug and Tiedemann, 1998; Draut et al., 2003), the first order pattern of $\delta^{13} \mathrm{C}$ changes found by Hodell and Venz-Curtis (2006) remains. Thus, they suggest that the observed reduced vertical and inter-basin gradient in the Atlantic during the mPWP is a result of either increased production of NADW and/or higher preformed $\delta^{13} \mathrm{C}$ values in Southern Component Water (SCW; deep water formed in the Southern Ocean). The simulation with NorESM-L (Zhang et al., 2013) further supports the alternative explanation of changes to preformed $\delta^{13} \mathrm{C}$ values in SCW. In a weakly stratified Southern Ocean, ventilation increases, and simulated water mass ages become younger in the intermediate to deep Southern Ocean, which is consistent with the observed high values of $\delta^{13} \mathrm{C}$ in the deep Southern Ocean (Site 1090/704) during the mPWP. Thus, the weak $\delta^{13} \mathrm{C}$ gradient does not necessitate a stronger AMOC. Further, the simulated weak stratification in the Southern Ocean in the mPWP is supported by productivity indicators (Sigman et al., 2004, see Sect. 2). Seen in this way, the best option for explaining the weak $\delta^{13} \mathrm{C}$ gradient is increased ventilation in the Southern Ocean, not an intensified AMOC.
Both the proxy data and the model-data comparison show that the Southern Ocean is the key region for understanding the mPWP $\delta^{13} \mathrm{C}$ record and changes in ocean circulation. However, simulations of Southern Ocean dynamics are highly model-dependent. In the PlioMIP, there are large differences in the simulations of Southern Ocean dynamics. Only NorESM-L simulates a weakly stratified Southern Ocean in the mid-Pliocene experiment.

One possible reason for the model-model discrepancy is the inability to resolve ocean eddies and the different choices for parameterizing vertical mixing. With eddies resolved, the simulated overturning cell in the Southern Ocean is found to be more sensitive to changes in wind stress, which causes larger changes in ventilation of the deep Southern Ocean, compared to non-eddy resolving simulations (Hallberg and Gnanadesikan, 2006). Furthermore, as shown by Bouttes et al. (2009), artificially reducing vertical mixing significantly increases ocean stratification and the ventilation of the Southern Ocean, impacting the exchange of $p \mathrm{CO}_{2}$ with the atmosphere. However, the Southern Ocean model-model discrepancy will be a crucial question that should be further addressed in the second phase of PlioMIP.

In summary, the eight coupled models (CCSM4, COSMOS, GISS-ModelE2-R, HadCM3, IPSLCM5A, MIROC4m, MRI_CGCM2.3, NorESM-L) in the PlioMIP do not simulate a strong mid-Pliocene AMOC as suggested by earlier proxy studies. There is no consistent increase in AMOC maximum strength (the maximum of the Atlantic meridional overturning streamfunction) among the models. Three models (CCSM4, IPSLCM5A, MIROC4m) simulate a decreased AMOC maximum strength, whereas the other five models do not. However, most models simulate a shallower AMOC cell, indicating a reduced influence of NADW at depth in the Atlantic basin. Moreover, the simulated ocean heat transport by the Atlantic in the mid-Pliocene experiments is similar to the pre-industrial, even in the simulations with increased AMOC maximums. As a consequence, the simulated high-latitude warming can not be explained as a direct response to increased strength of the AMOC. On the contrary, increased radiative surface forcing dominates the high-latitude surface warming observed during the mPWP.

Acknowledgements. This paper was jointly supported by the Strategic and Special Frontier Project of Science and Technology of the Chinese Academy of Sciences (Grant No. XDA05080803), the National 973 Program of China (Grant No. 2010CB950102), and the Earth System Modeling (ESM) project financed by Statoil, Norway. Z. Zhang and K. H. Nisancioglu acknowledge that the development of NorESM-L and experiments were supported by the ESM project. A. M. Haywood and A. M. Dolan acknowledge that the research leading to these results received funding from the European Research Council under the European Union's Seventh Framework Programme (FP7/2007-2013)/ERC grant agreement no. 278636. A. M. Dolan acknowledges the UK Natural Environment Research Council for the provision of a Doctoral Training 
Grant. D. J. Hill acknowledges the Leverhulme Trust for the provision of an early career fellowship with financial contributions made by the National Centre for Atmospheric Science and the British Geological Survey. B. L. Otto-Bliesner and N. A. Rosenbloom acknowledge that the research and computing for this project were supported by the US National Science Foundation and Department of Energy. W.-L. Chan and A. Abe-Ouchi acknowledge financial support from the Japan Society for the Promotion of Science and computing resources at the Earth Simulator Center, JAMSTEC. G. Lohmann received funding through the Helmholtz research programme PACES and the Helmholtz Climate Initiative REKLIM. C. Stepanek acknowledges financial support from the Helmholtz Graduate School for Polar and Marine Research and from REKLIM.

Edited by: C. Brierley

\section{References}

Bickert, T., Curry, W. B., and Wefer, G.: Late Pliocene to Holocene (2.6-0 Ma) western equatorial Atlantic deep-water circulation: Inferences from benthic stable isotopes, Proc. Ocean Drill. Prog. Sci. Results, 154, 239-254, 1997.

Billups, K., Ravelo, A. C., and Zachos, J. C.: Early Pliocene deepwater circulation: Stable isotope evidence for enhanced Northern Component Deep Water, Proc. Ocean Drill. Prog. Sci. Results, 154, 319-330, 1997.

Bouttes, N., Roche, D. M., and Paillard, D.: Impact of strong deep ocean stratification on the carbon cycle, Paleoceanography, 24, PA3203, doi:10.1029/2008PA001707, 2009.

Bragg, F. J., Lunt, D. J., and Haywood, A. M.: Mid-Pliocene climate modelled using the UK Hadley Centre Model: PlioMIP Experiments 1 and 2, Geosci. Model Dev., 5, 1109-1125, doi:10.5194/gmd-5-1109-2012, 2012.

Chan, W.-L., Abe-Ouchi, A., and Ohgaito, R.: Simulating the midPliocene climate with the MIROC general circulation model: experimental design and initial results, Geosci. Model Dev., 4, 1035-1049, doi:10.5194/gmd-4-1035-2011, 2011.

Chandler, M., Rind, D., and Thompson, R.: Joint investigations of the middle Pliocene climate II: GISS GCM Northern Hemisphere results, Global Planet. Change, 9, 197-219, 1994.

Chandler, M. A., Sohl, L. E., Jonas, J. A., Dowsett, H. J., and Kelley, M.: Simulations of the mid-Pliocene Warm Period using two versions of the NASA/GISS ModelE2-R Coupled Model, Geosci. Model Dev., 6, 517-531, doi:10.5194/gmd-6-517-2013, 2013.

Contoux, C., Ramstein, G., and Jost, A.: Modelling the midPliocene Warm Period climate with the IPSL coupled model and its atmospheric component LMDZ5A, Geosci. Model Dev., 5, 903-917, doi:10.5194/gmd-5-903-2012, 2012.

Dowsett, H. J., Cronin, T. M., Poore, R. Z., Thompson, R. S., Whatley, R. C., and Wood, A. M.: Micropaleontological evidence for increased meridional heat transport in the North Atlantic Ocean during the Pliocene, Science, 258, 1133-1135, 1992.

Dowsett, H. J., Thompson, R., Barron, J., Cronin, T., Fleming, F., Ishman, S., Poore, R.,Willard, D., and Holtz, T.: Joint investigations of the middle Pliocene climate I: PRISM paleoenvironmental reconstructions, Global Planet. Change, 9, 169-195, 1994.
Dowsett, H. J., Barron, J., and Poore, R.: Middle Pliocene sea surface temperatures: a global reconstruction, Mar. Micropaleontol., 27, 13-25, 1996.

Dowsett, H. J., Barron, J. A., Poore, R. Z., Thompson, R. S., Cronin, T. M., Ishman, S. E., and Willard, D. A.: Middle Pliocene paleoenvironmental reconstruction: PRISM2, Open File Rep., US Geol. Surv., avaliable at website: http://pubs.usgs.gov/of/ 1999/of99-535/, last access: July 2013, 99-535, 1999.

Dowsett, H. J., Robinson, M. M., and Foley, K. M.: Pliocene threedimensional global ocean temperature reconstruction, Clim. Past, 5, 769-783, doi:10.5194/cp-5-769-2009, 2009.

Dowsett, H. J., Robinson, M. M., Haywood, A. M., Hill, D. J., Dolan, A. M., Stoll, D. K., Chan, W.-L., Abe-Ouchi, A., Chandler, M. A., Rosenbloom, N. A., Otto-Bliesner, B. L., Bragg, F. J., Lunt, D. J., Foley, K. M., and Riesselman, C. R.: An assessment of confidence in Pliocene global sea-surface temperature, Nat. Clim. Change, 2, 365-371, 2012.

Draut, A. E., Raymo, M. E., McManus, J. F., and Oppo, D. W.: Climate stability during the Pliocene warm period, Paleoceanography, 18, 1078, doi:10.1029/2003PA000889, 2003.

Frank, M., Whiteley, N., Kasten, S., Hein, J. R., and O'Nions, K.: North Atlantic Deep Water export to the Southern Ocean over the past $14 \mathrm{Myr}$ : Evidence from $\mathrm{Nd}$ and $\mathrm{Pb}$ isotopes in ferromanganese crusts, Paleoceanography, 17, 1022, doi:10.1029/2000PA000606, 2002.

Frenz, M., Henrich, R., and Zychla, B.: Carbonate preservation patterns at the Ceara Rise-evidence for the Pliocne super conveyor, Mar. Geol., 232, 173-180, 2006.

Hallberg, R. and Gnanadesikan, A.: The role of eddies in determining the structure and response of the wind-driven Southern Hemisphere overturning: Results from the modeling eddies in the Southern Ocean project, J. Phys. Oceanogr., 36, 2232-2252, 2006.

Haug, G. H. and Tiedemann, R.: Effect of the formation of the Isthmus of Panama on Atlantic Ocean thermohaline circulation, Nature, 393, 673-676, doi:10.1038/31447, 1998.

Haywood, A. M. and Valdes, P. J.: Modelling Pliocene warmth: contribution of atmosphere, oceans and cryosphere, Earth Planet. Sc. Lett., 218, 363-377, 2004.

Haywood, A. M., Valdes, P. J., and Sellwood, B. W.: Global scale palaeoclimate reconstruction of the middle Pliocene climate using the UKMO GCM: initial results, Global Planet. Change, 25, 239-256, 2000.

Haywood, A. M., Dowsett, H. J., Otto-Bliesner, B., Chandler, M. A., Dolan, A. M., Hill, D. J., Lunt, D. J., Robinson, M. M., Rosenbloom, N., Salzmann, U., and Sohl, L. E.: Pliocene Model Intercomparison Project (PlioMIP): experimental design and boundary conditions (Experiment 1), Geosci. Model Dev., 3, 227-242, doi:10.5194/gmd-3-227-2010, 2010.

Haywood, A. M., Dowsett, H. J., Robinson, M. M., Stoll, D. K., Dolan, A. M., Lunt, D. J., Otto-Bliesner, B., and Chandler, M. A.: Pliocene Model Intercomparison Project (PlioMIP): experimental design and boundary conditions (Experiment 2), Geosci. Model Dev., 4, 571-577, doi:10.5194/gmd-4-571-2011, 2011.

Haywood, A. M., Hill, D. J., Dolan, A. M., Otto-Bliesner, B. L., Bragg, F., Chan, W.-L., Chandler, M. A., Contoux, C., Dowsett, H. J., Jost, A., Kamae, Y., Lohmann, G., Lunt, D. J., Abe-Ouchi, A., Pickering, S. J., Ramstein, G., Rosenbloom, N. A., Salzmann, U., Sohl, L., Stepanek, C., Ueda, H., Yan, Q., and Zhang, 
Z.: Large-scale features of Pliocene climate: results from the Pliocene Model Intercomparison Project, Clim. Past, 9, 191-209, doi:10.5194/cp-9-191-2013, 2013a.

Haywood, A. M., Dolan, A. M., Pickering, S. J., Dowsett, H. J., Mc-Clymont, E. L., Prescott, C. L., Salzmann, U., Hill, D. J., Hunter, S. J., Lunt, D. J., and Valdes, P. J.: On the identification of a Pliocene time slice(s) for data-model comparison, Philos. T. Roy. Soc. Lond., in press, 2013b.

Hillenbrand, C. D. and Futterer, D. K.: Neogene to Quaternary deposition of opal on the continental rise west of the Antarctic Peninsula, ODP Leg 178, Sites 1095, 1096 and 1101, Proc. Ocean Drill. Prog. Sci. Results, 178, 1-33, 2001.

Hodell, D. A. and Venz-Curtis, K. A.: Late Neogene history of deepwater ventilation in the Southern Ocean, Geochem. Geophy. Geosy., 7, Q09001, doi:10.1029/2005GC001211, 2006.

Jansen, E., Overpeck, J., Briffa, K. R., Duplessy, J.-C., Joos, F., Masson-Delmotte, V., Olago, D., Otto-Bliesner, B., Peltier, W. R., Rahmstorf, S., Ramesh, R., Raynaud, D., Rind, D., Solomina, O., Villalba, R., and Zhang, D.: Palaeoclimate, in: Climate Change 2007: The Physical Science Basis, edited by: Solomon, S., Qin, D., Manning, M., Chen, Z., Marquis, M., Averyt, K. B., Tignor, M., and Miller, H. L., Cambridge University Press, Cambridge, UK and New York, NY, USA, 433-497, 2007.

Jiang, D.-B., Wang, H.-J., Ding, Z.-L., Lang, X.-M., and Drange, H.: Modeling the middle Pliocene climate with a global atmospheric general circulation model, J. Geophys. Res., 110, D14107, doi:10.1029/2004JD005639, 2005.

Kamae, Y. and Ueda, H.: Mid-Pliocene global climate simulation with MRI-CGCM2.3: set-up and initial results of PlioMIP Experiments 1 and 2, Geosci. Model Dev., 5, 793-808, doi:10.5194/gmd-5-793-2012, 2012.

Koltermann, K. P., Gouretski, V. V., and Jancke, K.: Hydrographic Atlas of the World Ocean Circulation Experiment (WOCE), in: Volume 3: Atlantic Ocean, edited by: Sparrow, M., Chapman, P., and Gould, J., International WOCE Project Office, Southampton, UK, 2011

Lawrence, K. T., Sosdian, S., White, H. E., and Rosenthal, Y.: North Atlantic climate evolution through the Plio-Pleistocene climate transitions, Earth Planet. Sc. Lett., 300, 329-342, doi:10.1016/j.eps1.2010.10.013, 2010.

Lunt D. J., Haywood, A. M., Schmidt, G. A., Salzmann, U., Valdes, P. J., Dowsett, H. J., and Loptson, C. A.: On the causes of midPliocene warmth and polar amplification. Earth Planet. Sc. Lett., 321-322, 128-138, 2012.

Martínez-Garcia, A., Rosell-Melé, A., Jaccard, S., Geibert, W., Sigman, D. M., and Haug, G. H.: Southern Ocean dust-climate coupling over the past four million years, Nature, 476, 312-315, 2011.

McKay, R., Naish, T., Carter, L., Riesselman, C., Dunbar, R., Sjunneskog, C., Winter, D., Sangiorgi, F., Warren, C., Pagani, M., Schouten, S., Willmott, V., Levy, R., DeConto, R., and Powell, R. D.: Antarctic and Southern Ocean influences on Late Pliocene global cooling, P. Natl. Acad. Sci., 109, 6423-6428, doi:10.1073/pnas.1112248109, 2012.

Meehl, G. A., Stocker, T. F., Collins, W. D., Friedlingstein, P., Gaye, A. T., Gregory, J. M., Kitoh, A., Knutti, R., Murphy, J. M., Noda, A., Raper, S. C. B., Watterson, I. G., Weaver, A. J., and Zhao, Z. C.: Global climate projections, in: Climate Change 2007: The Physical Science Basis, edited by: Solomon, S., Qin, D.,
Manning, M., Chen, Z., Marquis, M., Averyt, K. B., Tignor, M. and Miller, H. L., Cambridge University Press, Cambridge, UK and New York, NY, USA, 770-772, 2007.

Miller, K. G., Wright, J. D., Browning, J. V., Kulpecz, A., Kominz, M., Naish, T. R., Cramer, B. S., Rosenthal, Y., Peltier, W. R., and Sindia, S.: High tide of the warm Pliocene: Implications of global sea level for Antarctic deglaciation, Geology, 40, 407410, doi:10.1130/G32869.1, 2012.

Naafs, D. A., Hefter, J., Acton, G., Haug, G. H., Martínez-Garcia, A., Pancost, R., and Stein, R.: Strengthening of North American dust sources during the late Pliocene (2.7 Ma), Earth Planet. Sc. Lett., 317-318, 8-19, 2012.

Oppo, D. W. and Fairbanks, R. G.: Variability in the deep and intermediate water circulation of the Atlantic Ocean: Northern Hemisphere modulation of the Southern Ocean, Earth Planet. Sc. Lett., 86, 1-15, 1987.

Ravelo, A. C. and Andreasen, D. H.: Enhanced circulation during a warm period, Geophys. Res. Lett., 27, 1001-1004, 2000.

Raymo, M. E., Hodell, D. A., and Jansen, E.: Response of deepwater circulation to initiation of Northern Hemisphere glaciation (3-2 Ma), Paleoceanography, 7, 645-672, 1992.

Raymo, M. E.,Grant, B., Horowitz, M., and Rau, G. H.: MidPliocene warmth: stronger greenhouse and stronger conveyor, Mari. Micropaleontol., 27, 313-326, 1996.

Raymo, M. E., Mitrovica, J. X., O’Leary, M. J., DeConto, R. M., and Hearty, P. J.: Departures from eustasy in Pliocene sealevel records, Nat. Geosci., 4, 328-332, 2011.

Rosenbloom, N. A., Otto-Bliesner, B. L., Brady, E. C., and Lawrence, P. J.: Simulating the mid-Pliocene Warm Period with the CCSM4 model, Geosci. Model Dev., 6, 549-561, doi:10.5194/gmd-6-549-2013, 2013.

Seki, O., Foster, G. L., Schmidt, D. N., Mackensen, A., Kawamura, K., and Pancost, R. D.: Alkenone and boron-based Pliocene $p \mathrm{CO}_{2}$ records, Earth Planet. Sc. Lett., 292, 201-211, 2010.

Sigman, D. M., Jaccard, S. A., and Haug, G. H.: Polar ocean stratification in a cold climate, Nature, 428, 59-63, 2004.

Sloan, L. C., Crowley, T. J., and Pollard, D.: Modeling of middle Pliocene climate with the NCAR GENESIS general circulation model, Mar. Micropaleontol., 27, 51-61, 1996.

Stepanek, C. and Lohmann, G.: Modelling mid-Pliocene climate with COSMOS, Geosci. Model Dev., 5, 1221-1243, doi:10.5194/gmd-5-1221-2012, 2012.

Trenberth, K. E. and Caron, J. M.: Estimates of meridional atmosphere and ocean heat transports, J. Climate, 14, 3433-3443, 2001.

Venz, K. A. and Hodell, D. A.: New evidence for changes in PlioPleistocene deep water circulation from Southern Ocean ODP Leg 177 Site 1090, Palaeogeogr. Palaeocl., 182, 197-220, 2002.

Venz, K. A., Hodell, D. A., Stanton, C., and Warnke, D.: A $1.0 \mathrm{Myr}$ record of Glacial North Atlantic Intermediate Water variability from ODP site 982 in the northeast Atlantic, Paleoceanography, 14, 42-52, 1999.

Wright, J. D. and Miller, K. G.: Control of North Atlantic Deep Water circulation by the Greenland-Scotland Ridge, Paleoceanography, 11, 157-170, 1996.

Wunsch, C.: The Total Meridional Heat Flux and Its Oceanic and Atmospheric Partition, J. Climate, 18, 4374-4380, 2005. 
Yan, Q., Zhang, Z.-S., Wang, H.-J., Jiang, D.-B., and Zheng, W.P.: Simulation of sea surface temperature changes in the middle Pliocene warm period and comparison with reconstructions, Chinese Sci. Bull., 56, 890-899, 2011.

Zhang, Z.-S., Nisancioglu, K., Bentsen, M., Tjiputra, J., Bethke, I., Yan, Q., Risebrobakken, B., Andersson, C., and Jansen, E.: Pre-industrial and mid-Pliocene simulations with NorESM-L, Geosci. Model Dev., 5, 523-533, doi:10.5194/gmd-5-523-2012, 2012.
Zhang, Z.-S., Nisancioglu, K., and Ninnemann, U.: Increased ventilation of Antarctic deep water during the warm mid-Pliocene, Nat. Commun., 4, 1499, doi:10.1038/ncomms2521, 2013. 